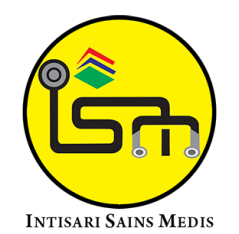

Published by Intisari Sains Medis

\section{The relationship between nutritional status, severity of diarrhea, and length of stay among pediatric patients with diarrhea in Wangaya Regional General Hospital}

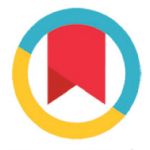

CrossMark

\author{
Mayland Margaretha Sunata ${ }^{1 *}$, I Wayan Bikin Suryawan ${ }^{1}$, Anak Agung Made Widiasa ${ }^{1}$
}

'Department of Child Health, Wangaya Regional General Hospital, Denpasar, Bali, Indonesia

\section{${ }^{*}$ Correspondence to:}

Mayland Margaretha Sunata, Department of Child Health, Wangaya Regional General Hospital, BaliIndonesia;

maylandmargarethasunata2@gmail.com.

Received: 2021-10-07

Accepted: 2021-12-06

Published: 2021-12-29

\section{ABSTRACT}

Background: Diarrhea is a disease still often encountered in society and is one of the biggest causes of death in children. Many factors contributed to the process of diarrhea, including poor nutritional status. According to the data from Riskesdas in 2018, 17.7\% of children under five in Indonesia still have nutritional problems. This study was conducted with the aim to know the relationship between nutritional status, the severity of diarrhea and the length of stay among pediatric patients with diarrhea.

Methods: This analytical study uses a cross-sectional design, with a total of 87 samples. Pediatric patients in Kaswari room from January 2019 to July 2020 with diarrhea or gastroenteritis, whose body's length or height, weight and duration of stay listed in the medical record were included in this study, while patients with congenital abnormality like Hirschsprung disease were excluded from this study. The data collected were analyzed using the Fisher test and Chi-square test.

Results: Out of 87 children, 49 (56\%) of them had normal nutritional status, 78 (87.4\%) children had modified vesikari score $\geq 11$, and 68 children had a length of stay $<5$ days (78.2\%). The results of bivariate analysis between nutritional status and diarrhea severity showed that there was no relationship between the two variables $(p=0.426)$. The same results were obtained in bivariate analysis between nutritional status and length of stay ( $p=0.916)$.

Conclusion: In this study, there was no relationship found between nutritional status, the severity of diarrhea and length of stay among pediatric patients with diarrhea in Wangaya Regional General Hospital.
Keywords: nutritional status, the severity of diarrhea, length of stay

Cite This Article: Sunata, M.M., Suryawan, I.W.B., Widiasa, A.A.M. 2021. The relationship between nutritional status, severity of diarrhea, and length of stay among pediatric patients with diarrhea in Wangaya Regional General Hospital. Intisari Sains Medis 12(3): 944-947. D0I: 10.15562/ism.v12i3.1163

\section{INTRODUCTION}

Diarrhea, a defecating condition in infants or children more than 3 times per day, accompanied by changes inconsistency, in which the feces becoming watery with or without mucous and blood, is still one of the health problems that are often encountered in everyday life. ${ }^{1}$ Diarrhea, together with pneumonia, is the major cause of mortality in children under 5 years old. ${ }^{2}$ One of nine deaths in children around the world is caused by diarrhea, making diarrhea the second leading death among children aged 5 years old. ${ }^{3}$

According to the diarrhea morbidity survey, there is an increasing incidence of diarrhea from 2000 to $2010 .^{4}$ Data from Riskesdas in 2018 stated that the prevalence of diarrhea in Indonesia has both decreased and increased in several provinces when compared to the data in 2013. ${ }^{5}$ Based on the data from Bali Health Profile in 2017, diarrhea and gastroenteritis rank $2^{\text {nd }}$ in the top 10 patterns of inpatient diseases at the Bali Provincial General Hospital in $2017 .{ }^{6}$ Denpasar city recorded diarrhea as a fairly high health problem, where diarrhea was even included in the top 10 list of diseases both in hospitals and public health centers. ${ }^{7}$
Various factors are known to play a role in the occurrence of diarrhea, one of which is the nutritional status (severe malnutrition). ${ }^{8}$ According to the data from Riskesdas in $2018,17.7 \%$ of children under five in Indonesia still have nutritional problems. ${ }^{5}$ The 2017 Bali Profile stated that the proportion of children with severe malnutrition is $3.4 \%$, while children with mild malnutrition are $14.4 \% .^{6}$ Research suggests that the state of malnutrition can make it easier for a person to catch infections. ${ }^{9}$ Several studies found that there is a relationship between nutritional status and diarrhea. ${ }^{10-16}$ However, there 
were also other studies that found no relationship between nutritional status and diarrhea.

Studies on the relationship between nutritional status and diarrhea have been carried out in various parts of the world, including Indonesia. Even so, not many took the data in Bali, especially in Denpasar. Based on what has been stated above, the researcher feels that the nutritional status and its relationship with diarrhea, including the severity of diarrhea and the length of hospitalization, are interesting things to study.

\section{METHODS}

This study is an analytical study with cross sectional design. The population in this study was all pediatric patients with diarrhea, hospitalized in the Kaswari room of the Wangaya Regional General Hospital from January 2019 to July 2020. In this study, there are 2 dependent variables, the severity of diarrhea and length of stay, so to find the minimum sample size, calculations are carried out using a formula for each variable, and then the calculation results with the larger number are selected. After calculating, the sample size obtained for this study was 87 samples.

The sampling in this study was carried out using consecutive sampling, and the data were taken from the medical records. Pediatric patients in Kaswari room from January 2019 to July 2020 with diarrhea or gastroenteritis, whose body's length or height, weight and duration of stay listed in the medical record were included in this study, while patients with congenital abnormality like Hirschsprung disease were excluded from this study.

In this study, diarrhea severity was assessed using the Modified Vesikari Score (MVS). The score has seven scoring parameters, namely, diarrhea duration, the maximum number of diarrheal stool/24-hour period, vomiting duration, the maximum number of vomiting episodes/24-hour period, maximum recorded fever, future healthcare visit and treatment. ${ }^{10,11}$ Total score $0-8$ in MVS is classified as a mild disease, 9-10 is classified as moderate, while 11 is classified as severe. ${ }^{11}$ For this study, the diarrhea severity was later divided into diarrhea severity with the total MVS score $<11$ and $\geq 11$.

Nutritional status, for this study, was assessed using 2006 WHO cuts off Z-score for children age 0-5 years old and CDC curve for children over 5 years old, followed with ideal body weight percentage according to the Waterlow criteria/classification. $^{12}$ The nutritional status was then divided into normal and abnormal nutritional status, in which abnormal nutritional status includes overweight, obesity, mild malnutrition and severe malnutrition. Length of stay was divided into $<5$ days and $\geq 5$ days.

After all, data had been collected, the

relationship between nutritional status and diarrhea severity was analyzed using the Fisher test, while the relationship between nutritional status and length of stay was analyzed using the Chi-square test.

\section{RESULTS}

Pediatric patients with diarrhea who were treated in the Kaswari room of Wangaya Regional General Hospital (January 2019July 2020), there were 87 data of pediatric patients obtained by consecutive sampling who were included in this study. All 87 subjects met the inclusion and exclusion criteria.

Table 1. Characteristics of sample

\begin{tabular}{|c|c|c|}
\hline Characteristics & $\begin{array}{c}\text { Frequency } \\
\text { (N) }\end{array}$ & Percentage (\%) \\
\hline \multicolumn{3}{|l|}{ Age } \\
\hline$<2$ years old & 47 & $54.00 \%$ \\
\hline 2 - 5 years old & 28 & $32.20 \%$ \\
\hline$>5$ years old & 12 & $13.80 \%$ \\
\hline \multicolumn{3}{|l|}{ Gender } \\
\hline Girl & 36 & $41.40 \%$ \\
\hline Boy & 51 & $58.60 \%$ \\
\hline \multicolumn{3}{|l|}{ Delivery Method } \\
\hline Vaginal delivery & 51 & $58.60 \%$ \\
\hline Cesarean delivery & 36 & $41.40 \%$ \\
\hline \multicolumn{3}{|l|}{ Mother's Gestational Age } \\
\hline Term & 83 & $95.40 \%$ \\
\hline Preterm & 4 & $4.60 \%$ \\
\hline \multicolumn{3}{|l|}{ Birth Weight } \\
\hline$<2500$ grams & 5 & $6.00 \%$ \\
\hline $2500-4000$ grams & 79 & $91.00 \%$ \\
\hline$>4000$ grams & 3 & $3.00 \%$ \\
\hline \multicolumn{3}{|c|}{ Breastmilk Consumption History } \\
\hline Exclusively breastfed & 53 & $60.90 \%$ \\
\hline Un-exclusively breastfed & 34 & $39.10 \%$ \\
\hline \multicolumn{3}{|l|}{ Nutritional Status } \\
\hline Normal & 49 & $56.00 \%$ \\
\hline \multicolumn{3}{|l|}{ Abnormal } \\
\hline Mild malnutrition & 25 & $29.00 \%$ \\
\hline Severe malnutrition & 3 & $4.00 \%$ \\
\hline Overweight & 2 & $2.00 \%$ \\
\hline Obesity & 8 & $9.00 \%$ \\
\hline \multicolumn{3}{|l|}{ Severity of Diarrhea } \\
\hline Modified vesikari score $<11$ & 11 & $12.60 \%$ \\
\hline Modified vesikari score $\geq 11$ & 78 & $87.40 \%$ \\
\hline \multicolumn{3}{|l|}{ Length of Stay } \\
\hline$<5$ days & 68 & $78.20 \%$ \\
\hline$\geq 5$ days & 19 & $21.80 \%$ \\
\hline
\end{tabular}


There were 36 girls and 51 boys, most of whom were less than 2 years old and hospitalized for less than 5 days. Nutritional status is divided into two groups, namely normal and abnormal, in which abnormal nutritional status includes overweight, obesity, mild malnutrition and severe malnutrition. In this study, it was found that most of the children had a normal nutritional status (56\%), mild malnutrition as much as $29 \%$, while overweight was found in $2 \%$ of children. Nine percent of children had obesity, and $4 \%$ had severe malnutrition. Of all children with normal nutritional status, $85.7 \%$ had severe diarrhea (MVS $\geq$ 11). In children with abnormal nutritional status, most of them were found to have severe diarrhea with a percentage of 89.5. More on the characteristics of the sample is shown in Table 1.

Even though most children in this study had diarrhea with MVS $\geq 11$, the bivariate analysis of the nutritional status and diarrhea severity by Fisher's exact test found that there was no relationship between the two ( $\mathrm{p}=0.426)$ (Table 2$)$. The same results, using the Chi-square test, were obtained in bivariate analysis between nutritional status and length of stay $(\mathrm{p}=0.916)($ Table 3$)$.

Table 2. Bivariate analysis between nutritional status and diarrhea severity

\begin{tabular}{llccccc} 
& & \multicolumn{4}{c}{ Diarrhea severity } \\
\cline { 3 - 5 } & & $\begin{array}{c}\text { Modified Vesikari } \\
\text { Score < 11 }\end{array}$ & $\begin{array}{c}\text { Modified Vesikari } \\
\text { Score } \geq \mathbf{1 1}\end{array}$ & P-value \\
\cline { 3 - 5 } & & $\mathbf{n}$ & $\%$ & $\mathbf{n}$ & $\%$ & \\
\hline \multirow{2}{*}{ Nutritional status } & Normal & 7 & $14.30 \%$ & 42 & $85.70 \%$ & 0.426 \\
& Abnormal & 4 & $10.50 \%$ & 34 & $89.50 \%$ & \\
& Total & 11 & $12.60 \%$ & 76 & $87.40 \%$ & \\
\hline
\end{tabular}

${ }^{*}$ Abnormal nutritional status: mild malnutrition, severe malnutrition, obesity, overweight $(\mathrm{p}<0.001)$.

Table 3. Bivariate analysis between nutritional status and length of stay

\begin{tabular}{|c|c|c|c|c|c|c|}
\hline & & \multicolumn{4}{|c|}{ Length of stay } & \multirow{3}{*}{ P-value } \\
\hline & & \multicolumn{2}{|c|}{$<5$ days } & \multicolumn{2}{|c|}{$\geq 5$ days } & \\
\hline & & $\mathbf{n}$ & $\%$ & $\mathbf{n}$ & $\%$ & \\
\hline \multirow{3}{*}{$\begin{array}{c}\text { Nutritional } \\
\text { status }\end{array}$} & Normal & 39 & $79.60 \%$ & 10 & $20.40 \%$ & 0.916 \\
\hline & Abnormal $^{*}$ & 29 & $76.30 \%$ & 9 & $23.70 \%$ & \\
\hline & Total & 68 & $78.20 \%$ & 19 & $21.80 \%$ & \\
\hline
\end{tabular}

Chi-square test

${ }^{\star}$ Abnormal nutritional status: mild malnutrition, severe malnutrition, obesity, overweight. hospitalization longer than usual. ${ }^{16}$ Of the 87 children in this study, it is known that most of the samples were less than 2 years old (54\%), $58.6 \%$ of the children are male. The results of this study are similar to a previous study conducted by Ermaya et al., where $90 \%$ of the sample were $\leq 2$ years old. ${ }^{13}$ This result was also in line with the existing theory where it is said that most episodes of diarrhea occur in the first 2 years of life, especially at 6-11 months of age when complementary feeding begin. ${ }^{3}$

Most of the children who experienced diarrhea in this study were found to have a normal nutritional status (56\%), while $44 \%$ had an abnormal nutritional status (mild malnutrition 29\%, obesity 9\%, severe malnutrition $4 \%$ and overweight $2 \%)$. It was also found that children with normal and abnormal nutritional status in this study tended to have modified vesikari scores with total points $\geq 11(85.7 \%$ and $89.5 \%)$ and tended to stay at the hospitals for less than 5 days (79.6\% and $76.3 \%)$. However, as described in the previous table, children with diarrhea who have abnormal nutritional status tend to experience more severe diarrhea $(85.7 \%$ vs. $89.5 \%)$ and tend to have longer hospitalization days ( $20.4 \%$ vs. $23.7 \%$ ). The results of this study are in line with a study done by Iskandar et al., wherein in their study, most of the subjects had diarrhea severity scores $\geq$ 11 , and the length of stay was less than 5 days. It was also stated that malnourished children tended to experience more severe diarrhea, longer duration of diarrhea and longer hospitalization. ${ }^{14}$

Nutritional status is known to affect the immune system and its protection against infectious agents..$^{15}$ In the bivariate analysis of this study, however, no significant result was found between the nutritional status and diarrhea severity variables ( $p$ $=0.426$ ), which means that there was no relationship between nutritional status and diarrhea severity in this study. This result is in contrast with several studies that had found a relationship between nutritional status and diarrhea severity, but a similar result was found in a crosssectional study by Ermaya et al., wherein their study no significant correlation between nutritional status and the severity of rotavirus diarrhea was found. ${ }^{13}$ Apart from these two variables, bivariate analysis 
between nutritional status and length of stay also shows no relationship with a $\mathrm{p}$-value of 0.916 . This result is in contrast with the finding of a study from Iskandar et al., where they found a significant association between nutritional status and length of stay but no significant association with diarrhea severity and duration of diarrhea. ${ }^{14}$

The insignificant results in this study may be caused by the small difference in the proportion between children with normal and abnormal nutritional status. As shown in the previous table, even though children with abnormal nutritional status tend to have severe diarrhea, children with normal nutritional status in this study also tend to experience severe diarrhea (modified vesikari score $\geq 11$ ). The situation in this study shows that both normal and abnormal nutritional status have the same possibility of experiencing severe diarrhea. This condition leads us to think about the possibility of other factors that might affect the result of this study.

Other factors that might affect the result in this study are the other confounding factors that were not examined in this study such as immunization or vaccination status, economic status (parent's income), therapy which had been given to the patients and other factors from the agent of infection who might also affect the severity of diarrhea and the length of stay in pediatric patients with diarrhea.

Another cause that might influence the result of this study is that the majority of the sample $(56 \%)$ have good nutritional status, followed by mild malnutrition in $29 \%$ of the sample. Severe malnutrition and obesity may have more influence on disease severity and length of stay. However, both nutritional statuses in this study are in a small percentage when compared to the normal nutritional status ( $9 \%$ and $4 \%$ versus $56 \%$ ).

Another weakness in this study is that the data used in this study are secondary data derived from the medical records and the small number of samples, which may affect the results of this study. This study might give different results if the data collection were done using primary data and with a larger number of samples.

\section{CONCLUSION}

From this study, two conclusions were obtained. Namely, there was no relationship between nutritional status and the severity of diarrhea in pediatric patients at Wangaya Hospital, and there was no relationship between nutritional status and length of hospitalization for pediatric patients with diarrhea at Wangaya Hospital.

\section{ETHICAL CLEARANCE}

This study was approved by the Health Research Ethics Committee, Wangaya General Hospital, Bali, Indonesia, prior to the study being conducted (No.060/ IX/KEP/RSW/2020). The research was conducted in accordance with several ethical principles, namely anonymity and confidentiality.

\section{CONFLICT OF INTEREST}

None declared.

\section{FUNDING}

This research received no specific grant from any funding agency in the public, commercial, or not-for-profit sectors. The authors are responsible for funding this study without involving grants, sponsors, or other sources of funding.

\section{AUTHOR'S CONTRIBUTION}

All authors have the same contribution in writing this research report.

\section{REFERENCES}

1. Soenarto Y. Diare kronis dan diare persisten. In: Juffrie M, editor. Buku Ajar GastroenterologiHepatologi Jilid I. Jakarta: Badan Penerbit IDAI; 2011. p.122.

2. World Health Organization. Ending Preventable Child Deaths from Pneumonia and Diarrhoea by 2025. GAPPPD. 2013. p1-16.

3. Centers for Disease Control and Prevention. Diarrhea: Common Illness, Global Killer. CDC. 2012. p1-5.
4. Kementerian Kesehatan Republik Indonesia. Situasi Diare di Indonesia. Kemenkes RI. 2011. p1-44.

5. Badan Penelitian dan Pengembangan Kesehatan Republik Indonesia. Laporan Nasional Riskesdas 2018. Kemenkes RI. 2019. p1-630.

6. Dinas Kesehatan Provinsi Bali. Profil Kesehatan Provinsi Bali 2017. Dinkes Prov Bali. 2018. p1255.

7. Dinas Kesehatan Kota Denpasar. Profil Dinas Kesehatan Kota Denpasar Tahun 2018. Dinkes Kota Denpasar. 2019. p1-220.

8. Juffrie M, Soenarto SSY, Oswari H, Arief S, Rosalina I, dan Mulyani NS. Buku ajar gastroenterologi-hepatologi. Jakarta: Badan Penerbit IDAI. 2011. p263-284.

9. Katona P, Katona-Apte J. The interaction between nutrition and infection. Clin Infect Dis. 2008;46(10):1582-1588. doi: 10.1086/587658.

10. Freedman SB, Eltorky M, Gorelick M; Pediatric Emergency Research Canada Gastroenteritis Study Group. Evaluation of a gastroenteritis severity score for use in outpatient settings. Pediatrics. 2010;125(6):e1278-e1285. doi: 10.1542/peds.2009-3270.

11. Schnadower D, Tarr PI, Gorelick MH, et al. Validation of the modified Vesikari score in children with gastroenteritis in 5 US emergency departments. J Pediatr Gastroenterol Nutr. 2013;57(4):514-519. doi:10.1097/ MPG.0b013e31829ae5a3.

12. Sjarif DR, Nasar SS, Devaera Y, Tanjung C. Rekomendasi Ikatan Dokter Anak Indonesia (Pediatric Nutrition Care). Jakarta: UKK Nutrisi dan Penyakit Metabolik. 2011. p1-14.

13. Ermaya YS, Prasetyo D, Sabaroedin IM, Soenarto Y. A Correlational study between Nutritional Status and Severity of Rotavirus Diarrhea in children under five years in Bandung, Indonesia. Journal of Gastroenterology and Hepatology Research. 2017. 6(6). p2490-2094. doi:10.17554/j.issn.2224-3992.2017.06.667

14. Iskandar WJ, Sukardi IW, and Soenarto, Y. Risk of nutritional status on diarrhea among under five children. Paediatrica Indonesiana. 2015. 55(4). p235-8. DOI: https://doi.org/10.14238/ pi55.4.2015.235-8.

15. Farhadi S, Ovchinnikov RS. The relationship between nutrition and infectious diseases: A review. Biomed Biotechnol Res J. 2018;2:16872. doi:10.4103/bbrj.bbrj_69_18.

16. Patwari AK. Diarrhoea and malnutrition interaction. Indian J Pediatr. 1999;66(1 Suppl):S124-S134.

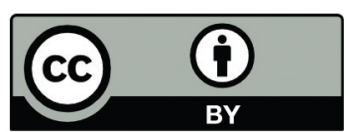

This work is licensed under a Creative Commons Attribution 